\title{
Short Communication: Analysis of the chromosome numbers of Zinnia elegans Jacq. in single, double, and pom-pom flowers
}

\author{
SAIFUDIN, SYALWA SHAFIRA, ASTARI DWIRANTI, ANDI SALAMAH \\ Cellular and Molecular Mechanisms in Biological Systems (CEMBIOS) Research Group, Department of Biology, Faculty of Mathematics and Natural \\ Sciences, Universitas Indonesia. Jl. Prof. Dr. Sudjono D Pusponegoro (Lingkat Kampus UI), Depok 16404, West Java, Indonesia. \\ Tel.: +62-21-7270163/78849009, Fax.: +62-21-78849010, •email: salamah@ sci.ui.ac.id
}

Manuscript received: 9 May 2021. Revision accepted: 19 June 2021.

\begin{abstract}
Saifudin, Shafira S, Dwiranti A, Salamah A. 2021. Short Communication: Analysis of the chromosome numbers of Zinnia elegans Jacq. in single, double, and pom-pom flowers. Biodiversitas 22: 2771-2777. Zinnia elegans Jacq. is highly valued as an ornamental plant with a variety of flower colors, sizes, and shapes. Polyploidization has been reported in Z. elegans with pom-pom flowers, nevertheless, the variation in chromosome numbers of various flower shapes has yet to be investigated. This study aimed to analyze the chromosome numbers of $Z$. elegans Jacq. cultivar "California Giant," "Lilliput," and "Cactus Flowered Mix" with single, double, and pom-pom flowers to determine their variations and identify the morphology of the flowers. Chromosomes were prepared using the squashing method, and images were analyzed using the Chromosome Image Analyzing System (CHIAS) IV. The minimum of 5 slides was prepared for each flower type from each cultivar. The results show that the three cultivars are diploid plants $(2 \mathrm{n}=24)$ with varying flower morphology. The single and double flowers of Z. elegans "Lilliput" and the single flower of "Cactus Flowered Mix" showed no variation in chromosome numbers. In contrast, chromosome number variation was found in the pom-pom flower of $Z$. elegans "California Giant" $(2 \mathrm{n}=22,24,48)$ and the double flower of "Cactus Flowered Mix" $(2 \mathrm{n}=9,13,15,24)$. Two cultivars, $Z$. elegans "California Giant" and Z. elegans "Cactus Flowered Mix," were successfully analyzed using CHIAS IV. Statistical analysis using a $t$-test $(\alpha=0.05)$ showed that the total chromosome length of $Z$. elegans "California Giant" $(2 n=24)$ was significantly greater than that of $Z$. elegans "Cactus Flowered Mix" $(2 n=24)$. Chromosome satellites were found in both cultivars.
\end{abstract}

Keywords: Chromosome image analyzing system IV, chromosome numbers, satellite, squashing method, Zinnia elegans

Abbreviations: CHIAS: Chromosome Image Analyzing System; NOR: Nucleolus Organizer Regions; rRNA: ribosomal RNA

\section{INTRODUCTION}

Zinnia elegans Jacq. is a member of the Asteraceae family that is highly valued as an ornamental plant. $Z$. elegans was first identified and scientifically named in the 1700s by Johann Gottfried Zinn, a German professor of botany who brought the plant to Europe. Dr. Zinn started cross-breeding these Zinnias with other Zinnias he found and so many forms were created through this hybridization technique. In the late 19 th and early 20th centuries, $Z$. elegans entered America and spread in several places, such as the West Indies, Australia, Italy, and Asia, including Indonesia. Since then, many forms of Z. elegans have been recognized and bred as ornamental plants (Bruno 2017). It is widely cultivated in Indonesia and commonly used in landscaping and flower borders and for cut flowers (Purwantoro and Jamhari 2017).

Inflorescence of $Z$. elegans has a capitulum consisting of two types of flowers, i.e. a ray floret with various bright colors and a yellow disc floret. The wild type of the species has a single flower, and its capitulum consists of only one purple or purple-pink ray floret layer (Misra and Misra 2017). The species is one of the most popular plants of the Asteraceae family cultivated through plant breeding resulting in hundreds of cultivars with various flower colors, sizes, and shapes. Plant breeding with various genetic methods such as hybridization and polyploidization occurs in Z. elegans (Metcalf and Sharma 1971). These genetic methods could affect the number of chromosome sets in plants, thus, the number may differ between wildtype species and cultivars (Aziz 2019).

The chromosome number of $Z$. elegans wild type is $2 n$ $=24$, with the basic chromosome number being $\mathrm{n}=\mathrm{x}=12$ (Torres 1963; Gupta and Koak 1976). Anantasaran (2007) found that Z. elegans cult. "Dreamland" and "Peter Pan" have diploid chromosomes $(2 \mathrm{n}=24)$, unlike cult. "Jungle," which has tetraploid chromosomes $(2 n=48)$. Gupta and Koak (1976) found that polyploidization in Z. elegans results in tetraploids, whose morphology differs from that of wild-type diploid individuals. These tetraploid plants form with a ray floret without a disc floret. The flower arrangement without a disc floret exhibits a pom-pom flower character, with many ray floret layers (Anderson 2007).

Polyploidization has been reported in Z. elegans with pom-pom flowers (Gupta and Koak 1976), the variation in chromosome numbers of various flower shapes has yet to be investigated. Moreover, data on the chromosome 
numbers of some Z. elegans cultivars are limited. Therefore, this study aimed to analyze the chromosome numbers of $Z$. elegans cultivar "California Giant," "Lilliput," and "Cactus Flowered Mix" with single, double, and pom-pom flowers to determine their variations and identify the morphology of the flowers.

\section{MATERIALS AND METHODS}

\section{Plant materials}

Zinnia elegans cult. "California Giant," "Lilliput," and "Cactus Flowered Mix" were analyzed in this study. The seeds of Z. elegans cult. were purchased from a local plant shop in Jakarta. Wet paper towels or filter paper provides an excellent medium for germinating seeds. The bright white tip of the root branch and the germinated roots from dried flowers (seeds) were used in the analysis. The root tips of sprouts were used as samples to determine the chromosome numbers after the roots reached $1-3 \mathrm{~cm}$.

\section{Procedures}

The chromosome preparation used was the squashing method employed by Anantasaran (2007) in several Zinnia species, with some modifications. The collected roots were cut into pieces of $1 \mathrm{~cm}$. The root tips were pretreated in cold water for 12 hours, followed by fixation with Carnoy's solution I (Farmer's solution; ethanol: glacial acetic acid ratio: 3:1) for 24 hours. The samples were then washed with distilled water and macerated with $1 \mathrm{~N} \mathrm{HCl}$ solution at $60^{\circ} \mathrm{C}$ for 15 minutes. They were then again washed with distilled water. The roots were subsequently soaked in an aceto-orcein solution for 20 minutes. The samples in the solution were then heated on a Bunsen burner for 5-10 seconds. Then, using a brush, the roots were placed on a slide. One to two drops of $45 \%$ acetic acid was added to the root tips, and the slides were covered with glass covers. Then, the glass covers were pressed using the tip of a brush until the root samples spread. The samples were then observed under a light microscope. Each flower type of single, double, and pompom from each cultivar was prepared and analyzed with a minimum of 5 slides.

\section{Data analysis}

Descriptive analyses were performed based on the photographs obtained and processed with Leica Application Suite EZ V2.0.0 software. Ideogram and quantitative analyses of chromosomes were performed using CHIAS IV, which was connected to ImageJ software (Kato et al. 2009; Kato 2015). Independent sample t-test was applied $(\mathrm{p}<0.05)$ in order to determine the significance between chromosome sizes.

\section{RESULTS AND DISCUSSION}

\section{Chromosome number}

The single and double flowers of $Z$. elegans cult. "Lilliput" and the single flower of "Cactus Flowered Mix" showed no variation in chromosome numbers $(2 \mathrm{n}=2 \mathrm{x}=$ 24). The representative flower and chromosome metaphase images of "Cactus Flowered Mix" single are shown in Figure 1. In contrast, variations were found in the double flower of "Cactus Flowered Mix" $(2 \mathrm{n}=9,13,15$, and 24) (Figure 2). Chromosome number variation was also observed in the "California Giant" pom-pom flower $(2 \mathrm{n}=$ 22, 24, and 48) (Figure 3). The chromosome number variation in different cultivars has also been reported by Anantasaran (2007) who evaluated the chromosome number of Z. elegans cult. "Dreamland" and "Jungle".
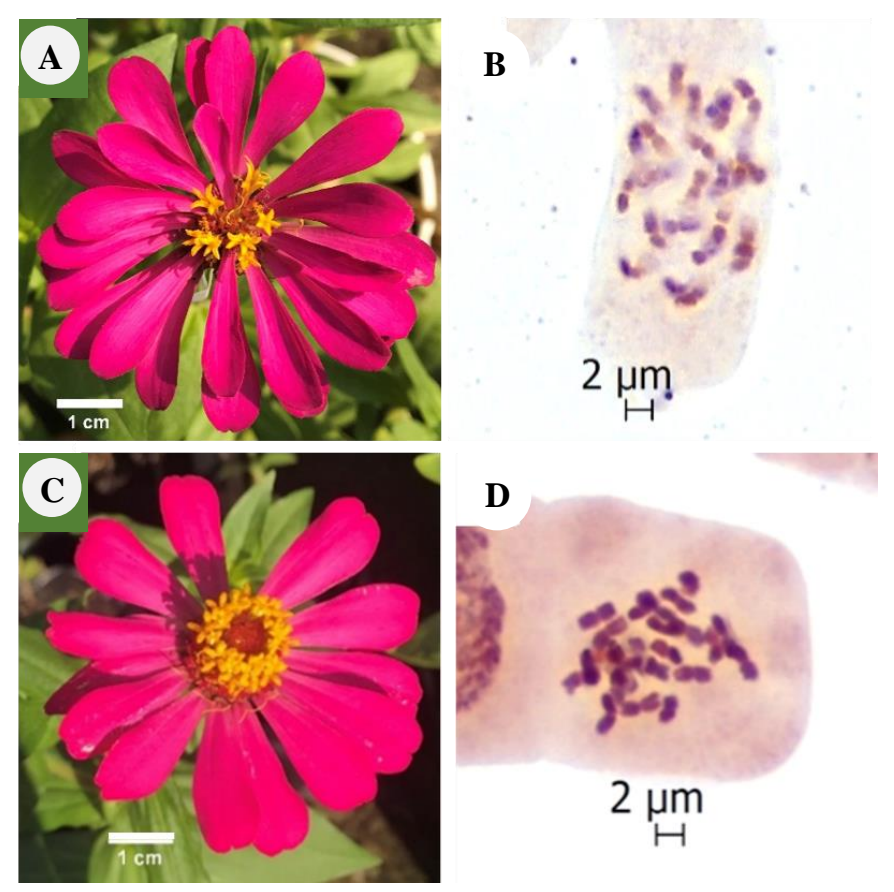

Figure 1. Flower and metaphase chromosome of Zinnia elegans. (A, B) cult. "Lilliput" double, and (C, D) cult. "Cactus Flowered Mix" single 

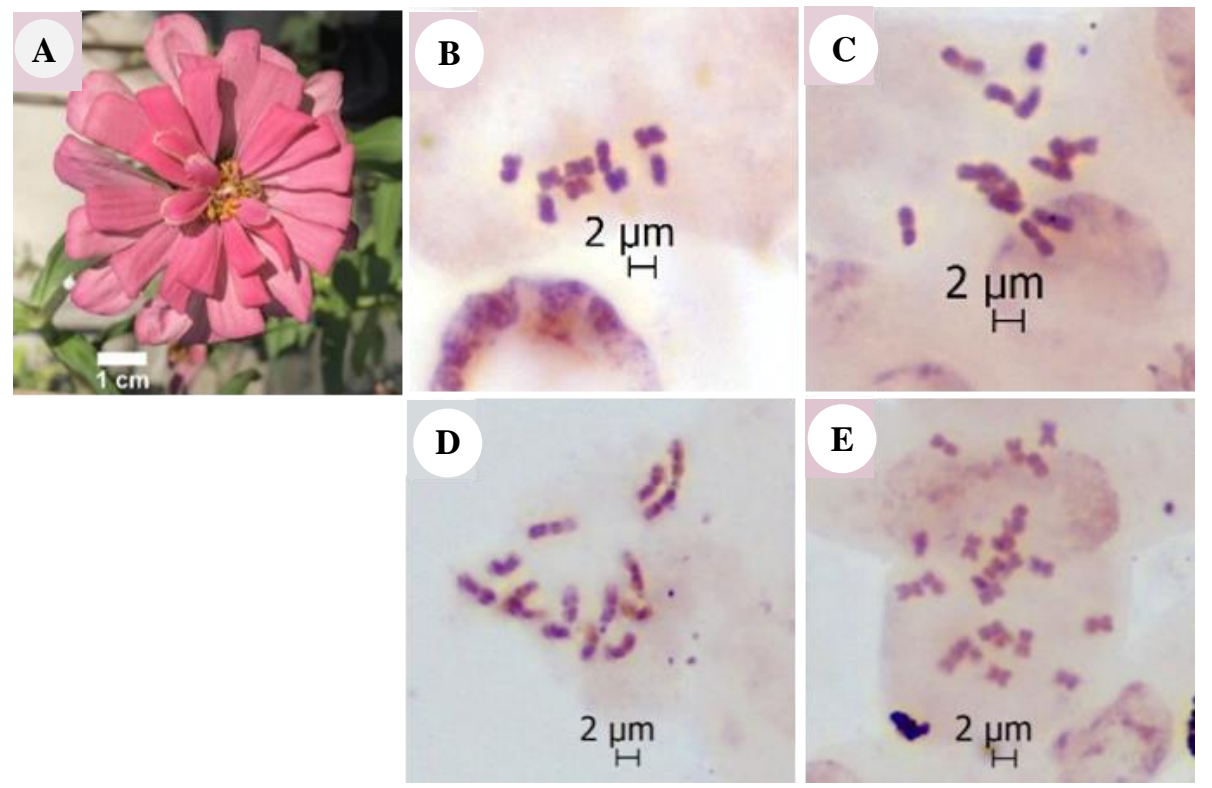

Figure 2. Flower and metaphase chromosome of Zinnia elegans "Cactus Flowered Mix" double. (A) flower, (B) chromosome 2n $=9$, (C) $2 \mathrm{n}=13$, (D) $2 \mathrm{n}=15$, and (E) $2 \mathrm{n}=24$.
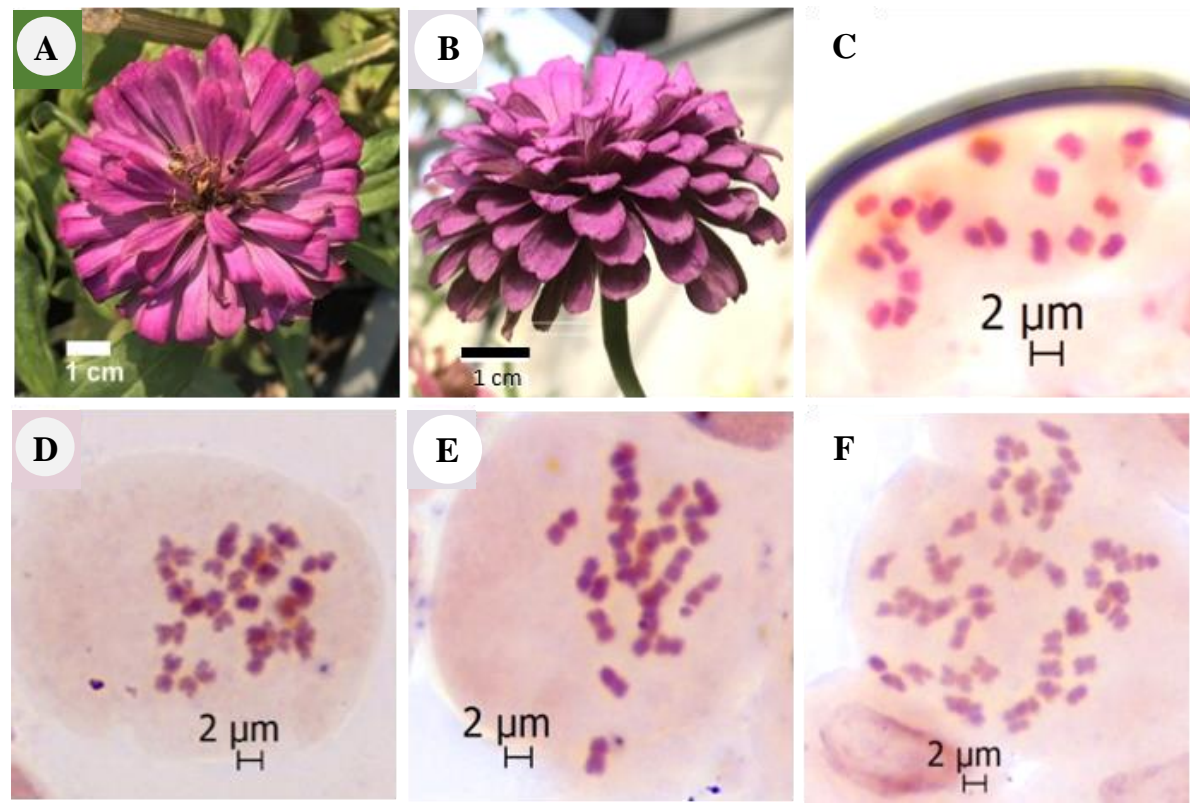

Figure 3. Flower and metaphase chromosome of Zinnia elegans "California Giant pom-pom." (A, B) flower, $(\mathrm{C})$ chromosome $2 \mathrm{n}=22$, $(\mathrm{D}, \mathrm{E}) 2 \mathrm{n}=24$, and $(\mathrm{F}) 2 \mathrm{n}=48$

The percentages of total diploid, euploid, and aneuploid cells in Z. elegans flowers cult. "Liliput", "Cactus Flowered Mix", and "California Giant" are presented in Table 1. The chromosome numbers are varied in the different cultivars. The "Lilliput" single and double flowers have the chromosome number of $2 n=28$ and $2 n=26$, respectively. The higher chromosome numbers were found in the "Cactus Flowered Mix" single and double flowers of $2 n=44$ and $2 n=49$, respectively. The highest number of chromosomes was found in the "California Giant" pompom flower $(2 n=87)$. Furthermore, not only diploid cells, the euploid cells were also found in the "California Giant" pompom, while the aneuploid cells were found in the "Cactus Flowered Mix" double $(2 \mathrm{n}=\mathrm{x}+3=15,2 \mathrm{n}=\mathrm{x}+1$ $=13,2 \mathrm{n}=\mathrm{x}-3=9)$ and "California Giant" pompom $(2 \mathrm{n}=$ $2 \mathrm{x}-2=22$.). The condition of cells or a tissue exhibiting chromosome number variation (different ploidy) is called mixoploidy. Mixoploidy can occur spontaneously and can also be induced (Prakash et al. 1988). Ranjbar et al. 2011 reported that mixoploidy in plant tissue underlies the phenomenon of gametophytic apomixis (agamospermy). An example of this phenomenon is the presence of tetraploid cells among diploid cells. In this study, the tetraploid cells were found in pom-pom flower of "Lilliput." 
Mixoploidy is also known as polysomaty. In our previous studies, we found that several Asteraceae species were mixoploid, such as Cosmos caudatus $(2 \mathrm{n}=2 \mathrm{x}+2=22$, $2 \mathrm{n}=3 \mathrm{x}=30, \quad 2 \mathrm{n}=3 \mathrm{x}+2=32, \quad 2 \mathrm{n}=3 \mathrm{x}+6=36, \quad 2 \mathrm{n}=4 \mathrm{x}=40)$, Elephantopus scaber $\quad(2 \mathrm{n}=2 \mathrm{x}-4=14, \quad 2 \mathrm{n}=2 \mathrm{x}=18$, $2 n=2 x+2=20,2 n=2 x+4=22)$, Tridax procumbens $(n=x=9$, $2 \mathrm{n}=2 \mathrm{x}=18,2 \mathrm{n}=3 \mathrm{x}=27,2 \mathrm{n}=4 \mathrm{x}=36,2 \mathrm{n}=5 \mathrm{x}=45$ ), Mikania micrantha $(2 \mathrm{n}=\mathrm{x}+6=24, \quad 2 \mathrm{n}=2 \mathrm{x}-4=32), \quad$ Sphagneticola trilobata $\quad(2 \mathrm{n}=2 \mathrm{x}+4=32, \quad 2 \mathrm{n}=4 \mathrm{x}-2=54), \quad$ Ageratum conyzoides $(2 \mathrm{n}=4 \mathrm{x}-3=37, \quad 2 \mathrm{n}=4 \mathrm{x}=40), \quad$ Cyanthillium cinereum $(\mathrm{n}=\mathrm{x}=9,2 \mathrm{n}=2 \mathrm{x}-2=16)$, Chromolaena odorata $(2 \mathrm{n}=4 \mathrm{x}=40,2 \mathrm{n}=5 \mathrm{x}-4=46,2 \mathrm{n}=6 \mathrm{x}=6)$, Synedrella nodiflora $(2 n=3 x+2=32, \quad 2 n=3 x+4=34, \quad 2 n=4 x-4=36, \quad 2 n=4 x-2=38$, $2 \mathrm{n}=4 \mathrm{x}=40)$, Youngia japonica $(2 \mathrm{n}=2 \mathrm{x}-4=14,2 \mathrm{n}=2 \mathrm{x}=18$, $2 \mathrm{n}=3 \mathrm{x}-1=26)$, Eclipta prostrata $(2 \mathrm{n}=2 \mathrm{x}=18,2 \mathrm{n}=2 \mathrm{x}+4=22)$, and Porophyllum ruderale $(2 \mathrm{n}=3 \mathrm{x}-2=28,2 \mathrm{n}=3 \mathrm{x}+2=32$, $2 n=3 x+3=33^{*}, 2 n=4 x-4=36,2 n=4 x=40$ ) (Salamah et al. 2018). According to Kashin et al. (2011), mixoploidy in Asteraceae is related to the apomixis phenomenon. Apomixis is an asexual process which results in seeds that are of the same genotype as that of the female parent. This process leads to the avoidance of meiosis, fertilizationindependent embryo development and autonomous development of the endosperm. Thus, apomixis results in polyploids, including mixoploid (Asker and Jerling 1992; Savidan 2000; Kantartzi and Roupakias 2010).

\section{Chromosome ideograms}

The results of the quantitative analysis of chromosome is shown in Table 2. The ideogram of Z. elegans "Cactus Flowered Mix" with chromosome number $2 \mathrm{n}=\mathrm{x}-3=9$ and karyotype formula $2 \mathrm{n}=\mathrm{x}-3=9=9 \mathrm{~m}$ are shown in Figure 4. The ideogram of "Cactus Flowered Mix" with chromosome number $2 \mathrm{n}=2 \mathrm{x}=24$ is shown in Figure 5 . The karyotype formula for the diploid cell is $2 n=2 x=24$ $=23 \mathrm{~m}+1 \mathrm{t}$. The chromosome ideograms presented in this study are the representatives of the well-spread chromosome samples.

The ideogram of Z. elegans "Cactus Flowered Mix" with chromosome number $2 \mathrm{n}=\mathrm{x}+3=15$ is shown in Figure 6 . The karyotype formula for the aneuploid cell is $2 \mathrm{n}=\mathrm{x}+3=15=1 \mathrm{M}+13 \mathrm{~m}(2 \mathrm{SAT})+1 \mathrm{sm}$. The ideogram of "California Giant" with chromosome number $2 \mathrm{n}=2 \mathrm{x}=$ 24 is shown in Figure 7. The karyotype formula for the diploid cell is $2 \mathrm{n}=2 \mathrm{x}=24=3 \mathrm{M}+20 \mathrm{~m}(\mathrm{SAT})+1 \mathrm{sm}+1$ st.

Table 1. Percentages of total diploid, euploid, and aneuploid cells in Zinnia elegans flowers

\begin{tabular}{lcccc}
\hline \multicolumn{1}{c}{ Cultivar } & $\mathbf{x}$ & Diploid cells $(\mathbf{2 x}), \mathbf{n}(\boldsymbol{\%})$ & Euploid cells $(\mathbf{4 x}), \mathbf{n}(\boldsymbol{\%})$ & Aneuploid cells, $\mathbf{n}(\boldsymbol{\%})$ \\
\hline "Lilliput" single & 24 & $28(100)$ & - & - \\
"Cactus Flowered Mix" single & 24 & $44(100)$ & - & - \\
"Lilliput" double & 24 & $26(100)$ & - & - \\
"Cactus Flowered Mix" double & 24 & $49(90.74)$ & - & $5(9.25)^{\mathrm{a}}$ \\
"California Giant" pom-pom & 24 & $87(94.56)$ & $3(3.26)$ & $2(2.17)^{\mathrm{b}}$ \\
Total & & 234 & 3 & 7 \\
$\%$ & 95.9 & 1.22 & 2.86 \\
\hline
\end{tabular}

Note: ${ }^{a} 2 \mathrm{n}=\mathrm{x}+3=15,2 \mathrm{n}=\mathrm{x}+1=13,2 \mathrm{n}=\mathrm{x}-3=9 ;{ }^{\mathrm{b}} 2 \mathrm{n}=2 \mathrm{x}-2=22$

Table 2. Chromosome number, size, and morphology of Zinnia elegans "Cactus Flowered Mix" and "California Giant"

\begin{tabular}{|c|c|c|c|c|c|}
\hline Cultivar & $\begin{array}{c}\text { Chromosome } \\
\text { number }\end{array}$ & $\begin{array}{c}\text { Greatest } \\
\text { chromosome } \\
\text { length }(\mu \mathrm{m})\end{array}$ & $\begin{array}{c}\text { Largest } \\
\text { chromosome } \\
\text { morphology }\end{array}$ & $\begin{array}{c}\text { Smallest } \\
\text { chromosome } \\
\text { length }(\mu \mathrm{m})\end{array}$ & $\begin{array}{c}\text { Smallest } \\
\text { chromosome } \\
\text { morphology }^{\mathrm{a}}\end{array}$ \\
\hline "Cactus Flowered Mix" & 9 & 2.323 & Metacentric & 1.588 & Metacentric \\
\hline "Cactus Flowered Mix” & 15 & 4.323 & Metacentric & 2.617 & Metacentric \\
\hline "Cactus Flowered Mix" & 24 & 2.558 & Metacentric & 1.441 & Acrocentric \\
\hline "California Giant" & 24 & 3.364 & Metacentric & 1.848 & Subtelocentric \\
\hline
\end{tabular}

Note: ${ }^{a}$ Morphology according to Levan et al. (1964) based on the arm ratio. Metacentric: arm ratio of 1.01-1.69; subtelocentric: arm ratio of 3.01-7; acrocentric: arm ratio of $>7$.
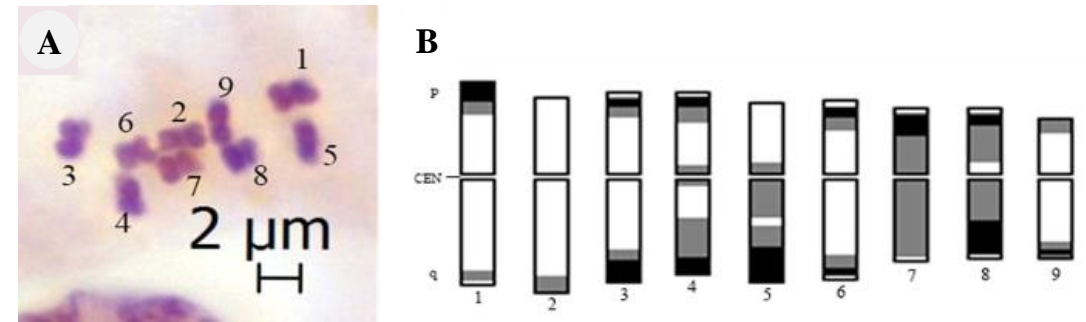

Figure 4. Ideogram of Zinnia elegans "Cactus Flowered Mix" $(2 n=9)$. (A) metaphase chromosomes $(2 n=9)$, and (B) ideogram based on chromosome condensation patterns. The long $\operatorname{arm}(\mathrm{p})$, short $\operatorname{arm}(\mathrm{q})$, and centromere (CEN) are shown in the ideogram. 

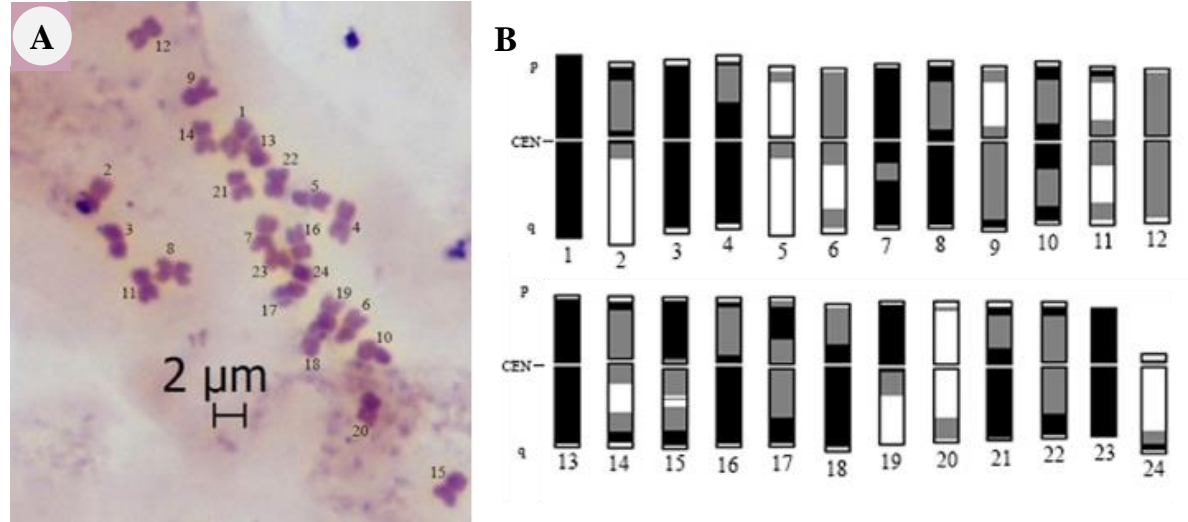

Figure 5. Ideogram of Zinnia elegans "Cactus Flowered Mix" $(2 n=24)$. (A) metaphase chromosomes $(2 n=24)$, and $(B)$ ideogram based on chromosome condensation patterns. The long arm (p), short arm (q), and centromere (CEN) are shown in the ideogram.
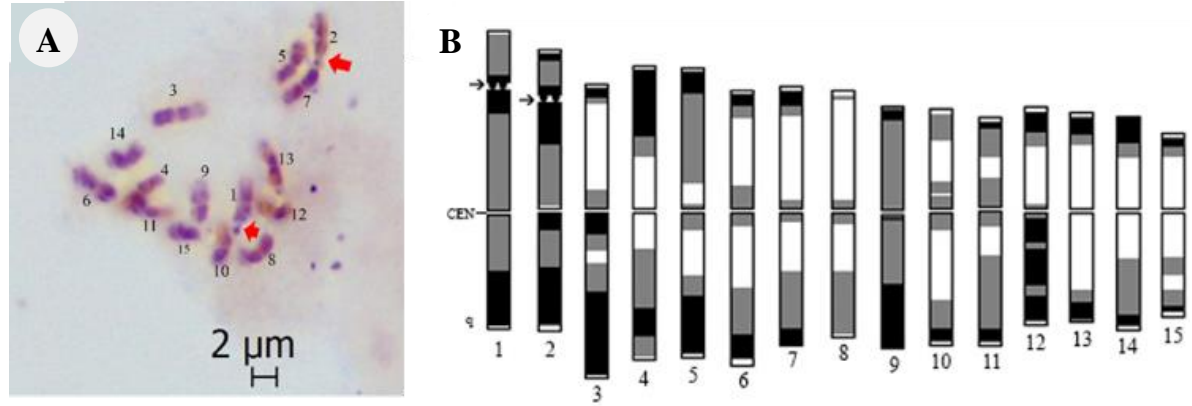

Figure 6. Ideogram of Zinnia elegans "Cactus Flowered Mix" $(2 n=15)$. Metaphase chromosomes $(2 n=15)(A)$ and ideogram based on chromosome condensation patterns (B). The long arm (p), short arm (q), and centromere (CEN) are shown in the ideogram. The arrows indicate secondary constrictions.
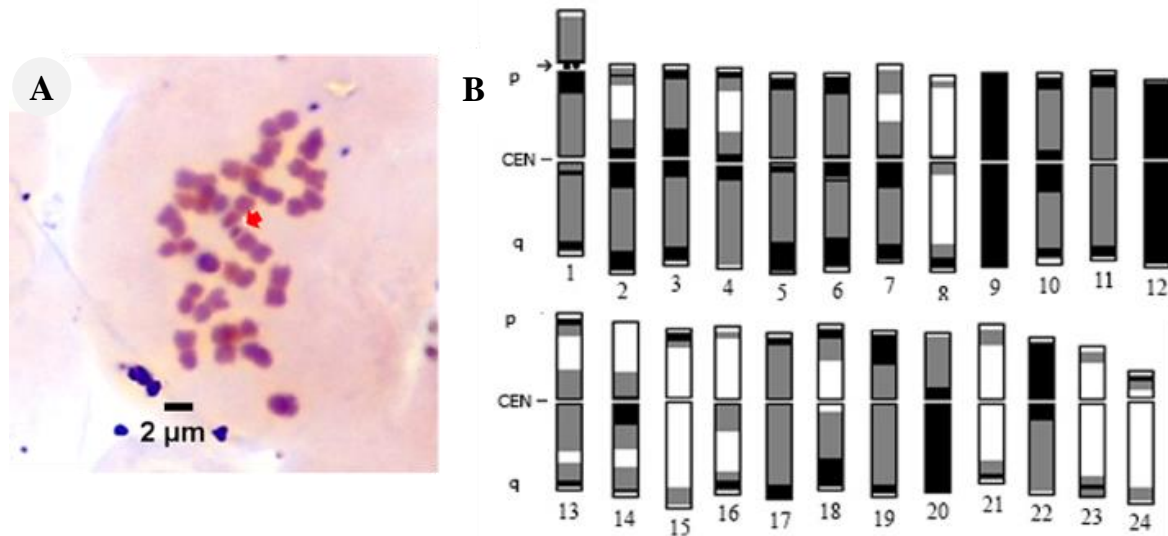

Figure 7. Ideogram of Zinnia elegans "California Giant" $(2 n=24)$. (A) Metaphase chromosomes $(2 n=24)$ and $(B)$ ideogram based on chromosome condensation patterns. The long arm (p), short arm $(\mathrm{q})$, and centromere (CEN) are shown in the ideogram. The arrow indicates a secondary constriction.

Chromosome length measurements were performed on Z. elegans cult. "Cactus Flowered Mix" $(2 \mathrm{n}=24)$ and "California Giant" $(2 \mathrm{n}=24)$. The $t$-test $(\alpha=0.05)$ indicated that the total chromosome length of "California Giant" $(61.374 \mu \mathrm{m})$ was significantly greater than that of "Cactus Flowered Mix" $(51.931 \mu \mathrm{m})$. The flower sizes of "California Giant" and "Cactus Flowered Mix" were 6.5$7.3 \mathrm{~cm}$ and $5.5-6 \mathrm{~cm}$, respectively. This result is consistent with Misra and Misra (2017) that "California Giant" is a cultivar with large flowers. The results also indicated a correlation between chromosome size and flower size in $Z$. elegans. Azizi et al. (2014) found a significant correlation between genome size ( $\mathrm{C}$ value) and karyotype data in Helichrysum (Asteraceae). The karyotype data included ploidy levels, total chromosome size, long arm, and short arm length. The results suggest that differences in 
chromosome structure may be related to changes in the DNA level (genome size). In Helichrysmum, a greater chromosome arm length, total chromosome length, and genome size are most likely associated with increased ploidy rates (polyploidization) during species adaptation and diversification. Genome size is also known to positively correlate with the total karyotype and average chromosome length in Echinops, Crepis, and Artemisia (Asteraceae) species (Du et al. 2017). Not only the differences between chromosome length of "California Giant" which was significantly greater than that of "Cactus Flowered Mix", the chromosome numbers of their diploid cells were also found to be different (Table 1). In addition, euploid cells were only found in the "California Giant". These results further indicate the correlation between chromosomal data (ploidy, chromosome length, chromosome number) with the phenotype of $Z$. elegans cultivar and their flower sizes.

The effect of genome size and polyploidy on the cell cycle time can impact the physiological and phenotypic characters. It is well known that polyploid induction can affect the genome size, changing the nucleus size and shape and the chromatin structure and arrangement. These changes can affect the phenotype through gene expression (Doyle and Coate 2019). Intraspecific variations in genome size can correlate with phenotypic variations caused by the percentage of repeated DNA sequences (El-Shehawi and Elseehy 2017).

Satellite chromosomes of Z. elegans were also found on prometaphase chromosomes derived from "Cactus Flowered Mix." Satellites of metaphase chromosomes were observed in "California Giant." All observed satellites were located on the short arm of the chromosome. On the "Cactus Flowered Mix" chromosome $(2 \mathrm{n}=15)$, satellites were observed on chromosomes number 1 and 2, which are thought to be a pair of homologous chromosomes. The sizes of chromosomes with satellites are shown in Tables 3 and 4 .

Table 3. Satellite chromosome sizes of Zinnia elegans "Cactus Flowered Mix" $(2 \mathrm{n}=15)$

\begin{tabular}{lcccc}
\hline $\begin{array}{c}\text { Chromosome } \\
\text { number }\end{array}$ & $\begin{array}{c}\text { Chromosome } \\
\text { length }(\boldsymbol{\mu m})\end{array}$ & $\begin{array}{c}\text { Long } \\
\text { arm } \\
(\boldsymbol{\mu m})\end{array}$ & $\begin{array}{c}\text { Short } \\
\text { arm } \\
(\boldsymbol{\mu m})\end{array}$ & $\begin{array}{c}\text { Arm } \\
\text { ratio }\end{array}$ \\
\hline 1 (without satellite) & 3.705 & 1.97 & 1.735 & 1.135 \\
1 (with satellite) & 4.323 & 1.97 & 2.352 & \\
2 (without satellite) & 3.587 & 1.97 & 1.617 & 1.218 \\
2 (with satellite) & 4.264 & 1.97 & 2.294 & \\
\hline
\end{tabular}

Table 4. Satellite chromosome size of Zinnia elegans "California Giant" $(2 \mathrm{n}=24)$

\begin{tabular}{lcccc}
\hline $\begin{array}{c}\text { Chromosome } \\
\text { number }\end{array}$ & $\begin{array}{c}\text { Chromosome } \\
\text { length }(\boldsymbol{\mu m})\end{array}$ & $\begin{array}{c}\text { Long } \\
\text { arm } \\
(\boldsymbol{\mu m})\end{array}$ & $\begin{array}{c}\text { Short } \\
\text { arm } \\
(\boldsymbol{\mu m})\end{array}$ & $\begin{array}{c}\text { Arm } \\
\text { ratio }\end{array}$ \\
\hline 1 (without satellite) & 2.569 & 1.327 & 1.242 & 1.068 \\
1 (with satellite) & 3.364 & 1.327 & 2.037 & \\
\hline
\end{tabular}

A satellite is a small terminal segment of a chromosome that is formed due to a secondary constriction (Irawan 2019). Satellites are generally smaller than the size of chromosomes and are located at the ends of the chromosome and connected to it by a thin thread (secondary constriction) (Figures 6 and 7). Satellite chromosomes are quite common in plants, such as in the diploid family of Compositae (Zhang et al. 2013). GarridoRamos (2015) comprehensively reviewed the satellite DNA in plants, and suggested that the satellite DNA may have an indispensable role in regulating cellular events and shows that sequence conservation is not needed to develop any of the different structural roles that may be assigned to the subtelomeric satellite DNA.

In general, each satellite chromosome is associated with a nucleolus, a spherical structure active from the telophase to the prophase at the ribosomal RNA (rRNA) synthesis site. Nucleoli are found in the nucleus and are associated with parts of the chromosome. The parts responsible for the formation of nucleoli are known as nucleolus organizer regions (NOR) (Singh 2018). NORs are usually located on satellites or secondary constrictions, but not all secondary constrictions contain NORs. NORs contain genes encoding the $45 \mathrm{~S}$ rRNA, which is the precursor of the $18 \mathrm{~S}, 28 \mathrm{~S}$, and $58 \mathrm{~S}$ rRNAs, and are therefore referred to as rRNA gene sites. Chromosomes that have NORs are known as nucleolar chromosomes. Generally, two nucleolar chromosomes are found in diploid cells. NOR is found in the chromosomes of animals and plants (Bhat and Wani 2017).

Satellite chromosomes were observed in two of the three cultivars studied, "Cactus Flowered Mix" and "California Giant." Puspita et al. (2020) reported that satellites cannot be observed in all cells. Successfully detecting the presence of satellites can be influenced by the accuracy of performing the squashing technique to obtain a clear chromosome constriction position in the metaphase or prometaphase. Moreover, determining the position of the constriction can be difficult in some plants with small and thick chromosomes. Thus, a specific marker is needed, such as CentO, CRR, alpha satellite sequence, etc. Singh (2003) reported that the conventional staining method can only be used to quantitatively determine the standard of a karyotype. Therefore, a comparative technique with a specific marker is needed to qualitatively identify individual chromosomes.

In conclusion, Z. elegans cult. "California Giant," "Lilliput," and "Cactus Flowered Mix" are uniformly diploid cultivars $(2 n=2 x=24)$ with variations in flower shape and ray floret color. Aneuploid cells are found in the double flower of "Cactus Flowered Mix" $(2 \mathrm{n}=9$, 13, and $15)$. Aneuploid $(2 n=22)$ and tetraploid $(2 n=48)$ cells are found in the pom-pom flower of "Lilliput." "California Giant" has a larger flower and chromosome size than "Cactus Flowered Mix." 


\section{ACKNOWLEDGEMENTS}

The authors thank the Directorate of Research and Development, Universitas Indonesia for providing financial support through a PUTI (Publikasi Terindeks Internasional) grant, contract number NKB-4231/UN2.RST/HKP.05.00/ 2020, on behalf of Andi Salamah.

\section{REFERENCES}

Anantasaran J. 2007. Cytogenetic and molecular characterization and in vitro culture of Zinnia species. [Thesis]. Universitas Prince of Songkla, Thailand.

Anderson NO. 2007. Flower breeding and genetics: Issues, challenges and opportunities for the $21^{\text {st }}$ century. Springer Science \& Business Media, California.

Asker SE, Jerling L. 1992. Apomixis in Plants. CRC Press, Florida.

Aziz IR. 2019. Plant chromosomes as genetic markers. Jurnal Teknosain 13 (2): 125-131. DOI: 10.24252/teknosains.v13i2.9638. [Indonesian]

Azizi N, Sheidai M, Mozaffarian V, Nourmohammadi Z. 2014. Karyotype and genome size analyses in species of Helichrysum (Asteraceae) Acta Bot Brasilica 28(3): 367-375. DOI: 10.1590/0102 $33062014 a b b 3136$

Bhat TA, Wani AA. 2017. Chromosome Structure and Aberrations Springer Nature, New Delhi.

Bruno G. 2017. The history of Zinnia flowers https://www.gardenguides.com/82720-history-zinnia-flowers.html.

Doyle JJ, Coate JE. 2019. Polyploidy, the nucleotype, and novelty: The impact of genome doubling on the biology of the cell. Int J Plant Sci 180 (1): 1-52. DOI: 10.1086/700636

Du Y, Bi Y, Zhang M, Yang F, Jia G, Zhang X. 2017. Genome size diversity in Lilium (liliaceae) is correlated with karyotype and environmental traits. Front Plant Sci 8: 1303. DOI: 10.3389/fpls.2017.01303

El-Shehawi AM, Elseehy MM. 2017. Genome size and chromosome number relationship contradicts the principle of Darwinian evolution from common ancestor. J Phylogenetics Evol Biol 5: 1-9. DOI: 10.4172/2329-9002.1000179

Garrido-Ramos. 2015. Satellite DNA in plants: More than just rubbish Cytogenet Genome Res 146: 153-170. DOI: 10.1159\%2F000437008

Gupta PK, Koak R. 1976. Induced autotetraploidy in Zinnia elegans Jacq. Cytologia 41: 187-191. DOI: 10.1508/cytologia.41.18

Irawan B. 2019. Molecular Genetics. Airlangga University Press, Surabaya. [Indonesian]
Kantartzi SK, Roupakias DG. 2010. Study of apomictic seed formation in interspecific, Gossypium barbadense x G. hirsutum, cotton hybrids. Int J Bot 6 (2): 164-169. DOI: ijb.2010.164.169

Kashin AS, Tsvetova MI, Demochko YA. 2011. Cytogenetic peculiarities of the genesis of apical meristem cells in case gametophytic apomixis (with reference to autonomous Asteraceae apomicts). Cytol Genet 45: 85-96. DOI: 10.3103/S009545271102006X

Kato S, Ohmido N, Hara M, Kataoka R, Fukui K. 2009. Image analysis of small plant chromosomes by using an improved system, CHIAS IV. Chromosome Sci 12: 43-50. DOI: 10.11352/scr.12.43

Kato S. 2015. Studies on the development of image analysis for plant research [Thesis]. Kobe University, Japan.

Levan A, Fredga K, Sandberg AA. 1964. Nomenclature for centromeric position on chromosomes. Hereditas 52: 201-220.

Metcalf HN, Sharma JN. 1971. Germ plasm resources of the genus Zinnia L. Econ Bot 25 (2): 169-181. DOI: 10.1111/j.16015223.1964.tb01953.x

Misra RL, Misra S. 2017. Commercial ornamental crops: Cut flowers. Kruger Brentt Publishers UK Limited, Middlesex.

Purwantoro A, Jamhari. 2017. Test of consumer preferences for flower character of kembang kertas (Zinnia elegans Jacq.). Agroista: Jurnal Agroteknologi 1 (1): 20-31. [Indonesian]

Prakash NS, Lakshmi N, Harini I. 1988. A note on spontaneous mixoploid in Capsicum. Curr Sci 57 (8): 435-436.

Puspita A, Setiawan AB, Purwantoro A, Sulistyaningsih E. 2020. Identification of homologous chromosomes through detection of nucleolus organizer regions by AgNO3 staining in shallot plants. J Bioteknologi \& Biosains Indonesia 7 (1): 9-17. DOI: 10.29122/jbbi.v7i1.3693. [Indonesian]

Ranjbar M, Karamian R, Nouri S. 2011. Diploid-tetraploid mixoploidy in a new species of Astragalus (Fabaceae) from Iran. Ann Bot Fenn 48: 343-351. DOI: 10.5735/085.048.0406

Salamah A, Oktarina R, Ambarwati EA, Putri DF, Dwiranti A, Andayani N. 2018. Chromosome numbers of some Asteraceae species from Universitas Indonesia campus, Depok, Indonesia. Biodiversitas 19 (6): 2079-2087. DOI: 10.13057/biodiv/d190613

Savidan Y. 2000. Apomixis: Genetics and breeding. Plant Breed Rev 18: 13-85. DOI: $10.1002 / 9780470650158 . c h 2$

Singh RJ. 2003. Plant cytogenetics second edition. CRC Press LLC, Boca Raton.

Singh RJ. 2018. Practical Manual on Plant Cytogenetics. CRC Press, Boca Raton.

Torres AM. 1963. Taxonomy of Zinnia. Brittonia 15 (1): 1-25. DOI: $10.2307 / 2805035$

Zhang Y, Zhu ML, Dai SL. 2013. Analysis of karyotype diversity of 40 Chinese Chrysanthemum cultivars. J Sys Evol 51 (3): 335-352. DOI: 10.1111/J.1759-6831.2012.00235.X 